УДК $81 ’ 42: 159.942 .3]: 81: 930.85(100)](477.75$ - 074)(045)

\title{
ГУМОРИСТИЧНИЙ ІНТРАДИСКУРС МОВНОЇ КАРТИНИ СВІТУ ОКУПОВАНОГО КРИМУ
}

\author{
КОРОБКА Г. О. \\ кандидат філософських наук, доцент \\ Харківська державна академія культури \\ galynak@ukr.net
}

\begin{abstract}
З порушенням територіальної цілісності України в мові з'явилися нові слова, вирази, характерні для періоду анексії-окупації Криму. Лексичні новотвори функціонують у рамках гумористичного інтрадискурсу та виконують одну з найважливіших функцій у сучасній сміховій культурі українців - висміювання опонента через жартівливу невідповідність загальноприйнятих норм. Проаналізовано варіант новомови “Кримнаша", який сформувався з початку анексії на півострові - стилю мислення, знівеченого політикою і пропагандою, у якому реальність доведена до абсурду. Дослідження дало змогу краще зрозуміти механізм основних мовних патернів (набір стереотипних фраз, висловлювань або назв, прийнятих у певній культурі або середовищі) мислення адептів “Кримнаша", що увійшли в мовну картину світу окупованого Криму. Особливу увагу звернено на коментарі й дописи українського блогера, який живе в Криму і під ніком КРИМський бандерівець веде російськомовний інформаційно-сатиричний щоденник "Новости Крымнаша". На основі прикладів 3 дайджесту КРИМського бандерівця показано строкату іронічно-саркастичну картину світу.

Ключові слова: гумористичний інтрадискурс, гумор, мовна картина світу, гра слів, неологізм, патерн, Кримнаш.
\end{abstract}

\section{THE HUMOROUS INTRADISCOURSE OF THE LINGUISTIC PICTURE OF THE WORLD OF THE OCCUPIED CRIMEA}

KOROBKA Halyna Olexandrivna, Candidate of Philosophical Science (PhD), Assistant Professor Kharkiv State Academy of Culture galynak@ukr.net

Introduction. The Crimea is the most remarkable example of the events of the recent years, where a language breakdown was caused by the violation of the geographical boundary. In contravention of the territorial integrity of Ukraine, new words, expressions specific to the period of the annexation-occupation of the Crimea appeared in the language. Lexical neologisms function as part of the humorous intradiscourse and perform one of the most important functions in the modern Ukrainian culture of laughter - having in derision an opponent through the humorous incongruity of the generally accepted rules.

Purpose. The aim of the paper is to examine certain lexical innovations, language patterns, as well as Internet memes, in the linguistic picture of the world of the occupied Crimea through the laughter world perception of reality.

Methods. During the study, the method of contextual interpretation analysis, as well as the method of direct observation of the material, followed by the generalization of the obtained results, was used. This approach made it possible to build linguistic units in the context of discourse analysis and enabled to identify new approaches to the "laughter communication" study from the standpoint of its effectiveness, based on the analysis of verbal and nonverbal communication factors that create a humorous effect and function within the framework of humorous intradiscourse.

Results. Evaluative factor is determining for the linguistic picture of the world, as it reproduces the peculiarities of the world perception paradigm of speakers, i.e., a certain "world picture". The study has enabled a better understanding of the mechanism of the main language 
patterns (a set of stock phrases, statements or naming units adopted in a particular culture or environment) of the "Krymnash" adherents' mentality included in the linguistic world view of the occupied Crimea. The list of the main language patterns is systematized and summarized. The paper presents an attempt to interpret part of the most important linguistic mechanisms that promoted the active spreading of the ideas of the Crimean occupation followers and influenced the public opinion and belief system; in particular, to render them through the humorous intradiscourse with comic interpretations. Extensive coverage is given to comments and posts of a Ukrainian blogger who lives in the Crimea and keeps the Russian-language information and satirical diary "Novosti Krymnasha" ("The Krymnash News") under the nickname of the CRIMEAN Banderite. The author reveals the ironic and sarcastic world picture of the diary.

Conclusion. The author concludes that lexical innovations, language patterns as well as Internet memes, created in the occupied Crimea and caused by the annexation of the peninsula, have a humorous effect in the linguistic picture of the world of Ukrainians and Ukrainian-centered inhabitants of the occupied Crimea through the laughter world perception of reality.

Keywords: humorous intradiscourse, humour, linguistic picture of the world, word-play, neologisms, pattern, Krymnash.

Формулювання проблеми та обгрунтування актуальності ії розв'язання. 3 початку відновлення незалежності у 1991 році Російська Федерація веде постійну цілеспрямовану інформаційну війну проти України: необ'єктивність, маніпуляції, перекручування фактів, відверті неприховані дезінформації й інсинуації та ін. Задля здійснення інформаційного опору важливо висвітлювати маніпулятивні мовні засоби, за допомогою яких російська пропаганда фальшує реальність, створюючи хибну картину світу, що безпосередньо позначається на мовній картині світу окупованого Криму.

Мова відіграє важливу роль у тому, як суспільство сприймає реальність і реагує на неї, особливо якщо воно перебуває в умовах окупації географічного, інформаційного, мовного та психологічного просторів. Відомий російський філософ, лінгвіст, культуролог і літературознавець Михайло Епштейн, який виступив з осудом російської збройної агресії проти України, зазначив, що Крим - найяскравіший приклад подій останніх років, де відбувся мовний злам через порушення географічного кордону (Туркова, 19 березня, 2016). Якщо перефразувати відомий вислів, то загальну тенденцію можна сформулювати так: хто в “російському” Криму живе, той в цирку не сміється, а “Кримнаш” став живим утіленням сюжетів геніального Джорджа Оруелла та уособленням свого варіанта новомови, який сформувався $з$ початку анексії на півострові - стилю мислення, знівеченого політикою і пропагандою, у якому реальність доведена до абсурду. Незважаючи на зовнішню комічність, ситуація складніша й сумніша, ніж це може здатися на перший погляд. Леонідас Донскіс (2015) зауважує, що “політичний перформанс Путіна багато в чому відображає новий і зловісний феномен XXI століття - втрату відчуття реальності”. Унаслідок розчинення реальності твориться інша реальність із розв'язуванням війн і вторгненням “у слабкі й незахищені країни або сіючи хаос деінде: усе це для того, щоб згодом позиціонувати себе як потугу, здатну повернути наші нібито втрачені мир і стабільність. Таким чином режим Путіна розважає і веселить свій народ (моє виділення - Г.К.), бо електорат прагне нового захопливого й напруженого трилера: реальної війни в Україні чи гібридної на Близькому Сході. Що ми дізналися завдяки вторгненню Росії на Схід України вкупі з окупацією та анексією Криму? Ми побачили, як легко зазомбувати майже весь російський народ, перетворивши його на колективного глядача теледурниць. Путін став убивцею-блазнем або злочинцем-шоуменом, що поєднав фанатизм, утрату відчуття реальності й любов споживацького суспільства до новинок, матеріальних цінностей і масових розваг в одній виставі” (Донскіс, 2015, с. 50).

Під час смертельної небезпеки і при відчутті втрати свободи людині властиво сміятися і жартувати, оскільки гумор і сміх досягають найвищої точки активності. Люди сміються над ворогом-окупантом, щоб подолати біль утрат у собі й одночасно отримати розрядку нервів 
при нестерпній напрузі тривожних днів. Висміювання агресора-ворога роззброює його. Адже, як висловився Микола Гоголь, людського сміху боїться кожен, навіть той, хто вже нічого не боїться. Вірогідно, тільки цим аспектом природи смішного можна пояснити спалахи гумору в гострих і кризових ситуаціях. Цитата О. П. Довженка - українського письменника та кінорежисера - "Тільки сміхом можна беззлобно знищити зло" допомагає якнайточніше охарактеризувати особливу рису української нації, що грунтується на неповторному почутті гумору, своєрідністю словесної культури - iї сміхотливість. Українець не тільки висміює очевидні вади країни-агресора, але й сміється з себе самого, здатен до самоіронії. Коли, наприклад, росіянин сміється з інших націй і національностей, то він сміється 3 когось це можна назвати компенсацією власних комплексів. А якщо людина сміється з себе, то вона нормальна, адекватна й здорова, без комплексів. Цей гумор не деструктивний, а конструктивний, він дає енергію і поле для розвитку мовної картини світу, яка, у свою чергу, створює специфічне забарвлення реального світу. Ірина Коротич (Коротыч, 2016) зазначає, що люди під час буремних подій 2013-2014 сміялися із спотвореного і перекрученого висвітлення подій на Майдані 3 боку російських 3МІ. Наводимо цитату мовою оригіналу задля збереження емоційнозабарвленої стилістики авторки: “Изначально всё освещение событий на Майдане со стороны российских СМИ было чудовищно переврано. Нам, бывшим тут, было немыслимо видеть то, что транслируется там. Там не просто белое называли чёрным и наоборот - там создавали некую альтернативную реальность - с еврейскими погромами, фашиствующими молодчиками, запретом русского языка, разгромленным и сожжённым, погружённым в хаос Киевом. Надо всем этим мы, расчищая снег на Майдане, в аккурат возле работающего без помех ювелирного бутика, смеялись. Помните, как мы смеялись? (моє виділення - Г.К.) Тут же очень технично российские СМИ, а также ольгинцы (проплачені кремлівські тролі - прим. моя - Г.К.) и примкнувшие к ним добровольцы начали нагнетать тему: "революция = гражданская война". Мы, помнится, хохотали: (моє виділення - Г.К.) какая война, вы о чём, болезные, кто с кем будет воевать? Мы хохотали, (моє виділення - Г.К.) зная, что никто, ни один человек в стране не пойдёт воевать за Януковича. Мы хохотали, (моє виділення - Г.К.) твёрдо зная, что никаких фашистов на Майдане нет, что националисты занимают предписанные им природой в любом обществе несколько процентов и никогда не будут править бал в стране под названием Украина. Хохотали русскоязычные мы, (моє виділення - Г.К.) зная, что ничто и никогда не угрожало тут нашей русскоязычности, и не будет угрожать. Во всём этом мы были правы" (Коротыч, 2016).

Метою статті $\epsilon$ відстеження певних лексичних новотворів, мовних патернів, а також інтернетмемів, що формують мовну картину світу окупованого Криму через сміхове світосприйняття дійсності.

У дослідженні використано метод контекстуального інтерпретаційного аналізу, а також метод безпосереднього спостереження над матеріалом з подальшим узагальненням отриманих результатів. Такий підхід дав змогу інтерпретувати мовні одиниці в руслі дискурс-аналізу й накреслити нові підходи до вивчення “сміхового спілкування" з позиції його ефективності на основі аналізу мовленнєвих і немовленнєвих факторів, які визначають його формування як інтелектуально-емоційної діяльності, створюють комічний ефект і функціонують у рамках гумористичного інтрадискурсу, що свідчить про структурування дискурсу й інконгруентність на дискурсивному рівні. Суть цього механізму - у додатковій інтенсифікації й інтерпретації суб'єктивної емоційно-оцінної ситуації немовленнєвої дійсності з урахуванням комплексу дискурсивно-мовленнєвих, мовно-стилістичних і жанрових факторів, які зумовлюють його формування й функціонування й, таким чином, створюють комічний ефект. Семантично інконгруентність виявляється в карикатурному зображенні образу, обігруванні двозначності; у плані прагматики - у висміюванні персонажа, розумінні його статусу у вигляді жартівливої невідповідності загальноприйнятих норм (Самохіна, 2012, с. 90-92). 
Аналіз попередніх досліджень і публікацій. Теоретичною базою статті послугували праці мовознавців, філософів, культурологів, які вивчали особливості формування та функціонування мовної картини світу. В. М. Манакін (2012) констатує, що в буденному розумінні картина світу "це калейдоскоп вражень людини від інформації про світ, які свідомість "колекціонуе" і опрацьовує” (с. 63), а "мова є засобом матеріалізації різноманітних картин світу, які створює свідомість" (с. 65). Водночас мовна картина світу самостійна і відіграє ключову роль серед інших картин світу (с. 66). Серед відомих учених, які досліджували мовну картину світу, В. фон Гумбольдт, Й. Л. Вайсгербер, Л. Вітгенштейн, Е. Сепір, Б. Ворф. Одним із перших ідею про мову як інструмент інтерпретації світу і “дух народу” висловив німецький мовознавець Вільгельм фон Гумбольдт. Він метафорично інтерпретував мовну картину світу як мовне коло: “Оскільки сприйняття і діяльність людини залежать від ії уявлень, то її ставлення до предметів цілком зумовлене мовою <...> кожна мова описує навколо народу, якому вона належить, коло, з меж якого можна вийти тільки в тому разі, якщо вступаєш в коло іншої мови” (цит. за Сабитова, 2013, с. 49). Термін “мовна картина світу” в науковий обіг увів Й. Л. Вайсгербер, який уважав, що саме мова визначає мислення, процес пізнання людини i, відповідно, іiі культуру, поведінку та всю цілісну картину світу (Манакін, 2012, с. 67-68). Американські мовознавці Едвард Сепір та Бенджамін Ворф розвинули гіпотезу лінгвальної відносності, за якою структура мови визначає мислення і спосіб пізнання реальності. Отже, у кожній мові відбивається певний спосіб сприйняття світу. Це означає, що "існування мовної картини світу зумовлене гносеологічним чинником - процесом пізнання, яке $є$ невід’ємною частиною сутності людини” (Манакін, 2012, c. 66). Мовна картина світу визначає ставлення людини до світу і задає норми поведінки, тому, можна стверджувати, що це світобачення крізь призму мови, відповідно, "в мові існують слова, інші мовні одиниці, що відображають зміст свідомості [...] Кожна мовна картина світу неповторна і певним чином впливає на мислення носіїв конкретної мови і культури" (там само). Варто зазначити, що культура також відображається у мові, “тому слово й інші одиниці мови набувають у мові культури додаткову культурну семантику, особливе символічне значення" (Сабитова, с. 72).

3 порушенням територіальної цілісності України у мові з'явилися нові слова, вирази, характерні для періоду анексії-окупації Криму. Цілком імовірно, що зі звільненням Кримського півострова від окупантів і поверненням його до територіальних меж України ці новотвори відійдуть до категорії історизмів. Але наразі означена проблематика заслуговує на окремий аналіз. Для мовної картини світу визначальним $€$ фактор оцінності, оскільки відтворює особливості світоглядної парадигми мовців, тобто певної “картини світу”. Ольга Кирилюк (2015), цитуючи дослідження Т. А. Космеди, наголошує, що поняття "картина світу” стало основним смисловим базисом, на якому тримається вся логіко-семантична система мови, а факт відображення в мові світогляду і світовідчуття як окремих індивідів, так і цілих людських груп, дозволяє вважати мову специфічним знанням, поряд із знанням інтуїтивним, безпосереднім та науковим, теоретичним (c. 53). Ольга Кирилюк (2015) досліджує деякі лексичні новотвори, які пов’язані з темою цієї розвідки, зокрема ті, що виникають унаслідок природної реакції мовців, поширюються переважно через Інтернет в коментарях, блогах, дописах. Серед них є лексеми, пов'язані з російською агресією у Криму: “сепари”, “окупендум”, “вата”, “кримтроль”, “скримздити”, “зелені чоловічки”, “русскомірии”, “рамазмі” та ін. (Кирилюк, 2015, с. 54). “Дієслово “скримздити”, яке використовується доволі активно, має у німецькій мові свій аналог krimmen, що означає "незаконно відхопити" (Туркова, 19 березня, 2016). $Є$ такі неологізми, що сформувалися внаслідок зрощення двох слів в одне: Путлер (Путін + Гітлер); Путінг (Путін + мітинг) - назва масових заходів на підтримку президента Росії Володимира Путіна; окупендум (окупація + референдум) - оказіональна назва референдумів, проведених у Криму 
та на території Луганської і Донецької областей під час їхньої окупації російськими військами (Кирилюк, 2015, с. 55), КРИМіналітет (Крим + крим-іналітет), Кримль (Крим + Кр-емль) вживається у значенні “півострів Крим, окупований Росією” (Кирилюк, 2015, с. 56).

Словосполучення "зєльониє чєловєчкi”, “вєжлівиє люді", які увійшли в лексикон з початком анексії-окупації, продемонстрували, що військових без знаків розрізнення, які захопили кримські адміністративні установи, можна гібридно називати словами з мирною конотацією. Так, Ольга Кирилюк (2015) зазначає, що “в надії “відбілити” своє вторгнення в Крим, пропагандою був придуманий евфемізм ввічливі люди (рос. вежливые люди) на позначення солдатів російської армії” (с. 56). Причому словосполучення “зельониє чєловєчкі" використовують переважно українці, як жертва агресії, а “вєжлівиє люді" - росіяни. У пропагандистських цілях “ввічливі людu” мали стати для проросійських громадян образом воїнів-визволителів, які приїхали захищати мирні міста і села від “фашистів-бандерівців”. Вони ввічливі, привітні, усміхнені, охоче фотографуються з дітьми й молодими жінками. У свідомості мовців не подразнюються канали пам'яті, які виринули б при згадці слів солдати, військові, армія і однозначно викликали б негативні асоціати. Для посилення позитивної оцінки і кращого впливу на реципієнта були придумані гасла із зазначеним терміном: "Ввічливість міста бере" (рос. Вежливость города берет). Цей вислів працює на підміні понять - “агресія - ввічливість”: коли міста беруть армії це сприймається, як агресія, але ніхто не бачить нічого поганого в тому, що частину території іншої країни відібрали “ввічливо”. Адресат, на якого розрахована ця мовна маніпуляція, сприймає подію як благородний вчинок” (Кирилюк, 2015, там само). “Експерти вважають, що слоган "Вежливые люди" перетворюється в новий символ Збройних сил Росії, а російські філологи пояснюють його популярність комічним ефектом (моє виділення $-Г . К$.), закладеним у визначенні “ввічливі” щодо збройних сил” (Масенко, 23 Август 2017). Він набув такої широкої популярності у РФ, що “навіть зареєстрували бренд “Вежливые люди” та почали продавати футболки, на яких зображено портрет Путіна і написано “самый вежливый из людей”. Це не іронія. А тут це навпаки вживається іронічно, тобто “вєжлівиє люді” у зворотному значенні, тому що ввічливі люди насправді так не чинять” (Туркова, 19 березня, 2016).

На особливу увагу заслуговують коментарі й дописи українського блогера, який живе в Криму і під ніком КРИМський бандерівць веде російськомовний інформаційно-сатиричний щоденник "Новости Крымнаша", який активно засуджує російську окупацію Кримського півострова, виходить на основі зібраних фактів на новинних сайтах та з повідомлень реальних мешканців Кримського півострова в соціальних мережах, особистих спостережень автора, оповідань близьких і друзів, скарг мешканців півострова на окупаційну владу. У дайджесті КРИМського бандерівця вимальовується строката іронічно-саркастична картина світу, оскільки блогер відверто знущається з безглуздої окупаційної влади, висміюючи нікчемність усіх подій, які відбуваються на півострові. Автор щоденника чинить інформаційний опір російській пропаганді на території півострова, висвітлює, що насправді відбувається в Криму, “чтобы все знали, что такое "русский мир". Если сегодня мы промолчим о ком-то, завтра могут промолчать и про нас" (КРЫМский бандеровец). Тут і надалі залишаємо цитати КРИМського бандерівця в оригіналі, тобто російською мовою, оскільки саме так можна влучно передати яскравий сміховий колорит світогляду автора та відтворити гумористичний інтрадискурс мовної картини світу окупованого півострова. Назва блогу походить від поширеного неологізму “Кримнаш”, який активно пропагували під час інформаційної війни серед місцевого населення Криму. Варто відзначити, що КРИМський бандерівець принципово пише слова Росія та Путін з малої літери (Новости Крымнаша, 30 травня 2017).

“Крымнаш" (укр. "Кримнаш") - найвідоміший російськомовний неологізм, що виник та набув популярності в Росії на тлі підготовки та здійснення російської збройної агресії проти України та під час анексії Криму. Згодом неологізм поширився і в Україні як глузливий інтернет-мем, іноді - разом зі своїм глузливим дзеркальним відбиттям “Намкриш" (Крымнаш, 
4 листопада 2017). "Кримнаш" часто використовують у сатиричному контексті для позначення “патріотів”, які експресивно виражають захоплення анексією Криму з гаслом: “Крим наш!”. Тобто з лінгвістичного погляду його можна кваліфікувати і як іменник, i як вигук. Він фігуруе в жартах і анекдотах. Наприклад: “Російські жінки під час пологів кричать тепер не “мама!”, а “Крим наш!”. Сергій Стельмах висловлює думку, що “Крымнаш” став “концентрованим відображенням перевернутої російської дійсності. [...] Російська "влада" намагається постійно тримати кримчан в отруйній атмосфері “русской весны” - фальшивого вічного свята і карнавалу" (Стельмах, 07 Октябрь 2016). А за спостереженнями КРИМського бандерівця "Крымнаш все более становится чемоданом без ручки, дно которого трещит по швам от камней с неба и завываний разочарованных предателей” (моє виділення - Г.К.), (КРЫМский бандеровец).

Для наочності варто докладніше зупинитися на основних мовних патернах (набір стереотипних фраз, висловлювань або назв, прийнятих у певній культурі або середовищі) мислення адептів “Кримнаша”, що впевнено увійшли в мовну картину світу окупованого Криму. Перелік наведених нижче мовних патернів - це спроба розшифрувати частину найважливіших лінгвальних механізмів, які сприяли активному насаджуванню ідей адептів окупації Криму та слугували чинником впливу на громадську думку і систему переконань; зокрема, представити їх через гумористичний інтрадискурс із комічними тлумаченнями. Оскільки мова спілкування у Криму переважно російська, то наводимо мовні патерни в їхньому оригінальному звучанні, щоб точніше передати сутність одиниць:

Русский мир - фантасмагорична ідея експансії простору Р.П.Д.Л. (“Русскіх По Духу Людей”), за основу якої взята російська мова - тобто поєднання всіх російськомовних людей в одну спільноту, незалежно від державної належності. "Смешно наблюдать, как мои ватные соседи потирают лысину, и все чаще задаются вопросом: зачем нам этот “русский мир”? Но поздно” (моє виділення - Г.К.), (КРЫМский бандеровец).

Многонаииональный русский народ - нова історична спільнота людей у “Кримнаші”.

Русская весна - низка епохальних подій, реакція Кремля на нахабне втручання американців у внутрішні справи Росії в Києві, Криму та на Донбасі.

Президент Владимир Путин - великий вождь і вчитель. Інша версія: В.В.П. - Вождь Всєх Патріотовъ (також скорочення від Володимир Володимирович Путін). Натхненник "русской весны”. Приєднав Крим, позбавивши його мешканців українських продуктів, електрики, води і прав людини.

Хитрый план Путина - один з основоположних символів віри “Кримнаша”, священна скрижаль і книга заклинань. Як мінімум, адепти повинні знати два найсильніших заклинання: "Путин всех переиграл" та "Украина скоро развалится".

Киселев в телевизоре - верховний жрець, заклинатель, геополітичний некромант. Має підвищену енергетику. Кисельову досить тричі прочитати “Путин всех переиграл”, як американці вкриваються ядерним попелом.

“Хоть камни с неба" - катарсис, процес очищувального впливу на “кримнашистів" різних позитивних чинників: відсутність електрики, погана якість продуктів, низькі зарплати, вбита медицина, розвалене ЖКГ, злодійство і бездарність чиновників. КРИМський бандерівець регулярно рахує й нагадує, який день “каменепаду в Криму” на цей час. "Рухнувшие на голову камни с неба в виде мизерных зарплат, угробленной медицины, социальных проблем и ограничений, связанных с санкциями, ещё больше обозлили ватный планктон, рассчитывающий на внеземной рай после своего предательства, как показывал “Первый канал" (моє виділення - Г.К.), (КРЫМский бандеровец). Олександр Коноваленко в сатиричногумористичному журналі “Перець. Весела республіка” надрукував такий чотиривірш:

Повернулись до рідної гавані,

До Росії - країни чудес!

Тільки замість небесної манни 
У “Кримнаші" - каміння з небес (моє виділення - Г.К.), (Чотиривірш Олександра Коноваленка, 2017). КРИМський бандерівець пропонує збирати каміння з неба у мішки. "Потім, коли кримнаши через Керченську протоку переправлятися будуть, передасте їм. Каміння стане їм у нагоді” (КРЫМский бандеровец).

“Умереть в России” - вища мета, фінальна стадія “Кримнаша”, довгоочікуваний результат "камней с неба". Яскраво втілюється в життя у сфері медичних послуг. КРИМський бандерівець наводить такий приклад: “В свете программы "Умереть в россии” фраза на двери кабинета ялтинской поликлиники “Живой очереди нет” звучит зловеще” (моє виділення - Г.К.), (КРЫМский бандеровец).

"Смех Искандеров", також "Смешные санкиии" - сеанс колективного заспокоєння, що санкції, запроваджені Заходом, не страшні, а смішні, тобто навіть корисні (див. також Яковенко, 27/07/2017). “Смешные санкции веселят феодосийцев: “Как в обход санкциям заказать товар в Крым на Ебэе или Амазоне???” (моє виділення - Г.К.), (КРЫМский бандеровец). Спостерігаються інші варіанти у блозі: “не смешите Искандеры”, “Ржание Искандеров хорошо слышно в Крыму", "Россети” боятся заходить в Крым из-за санкций, от которых больше не ржут Искандеры”, “Хохот Искандеров", “Искандеры снова ржут”, "Хохот Искандеров смешит моряков-предателей”, “Что за звук раздается? Это хохочут Искандеры. Обхохатываются" (моє виділення - Г.К.), (КРЫМский бандеровец).

Вставание с колен - нескінченна боротьба Росії з “ненависним Заходом", яка завжди закінчується перемогою останнього. “Злые языки поговаривают, что США и Запад очень долго пытались поставить россию на колени, но потом бросили это гиблое дело - россия так и осталась лежать". "Оккупанты в Крыму хотят засекретить данные об инвесторах. Какие инвесторы? Ахахах)))))) Встаем с колен раком к верху”. “Вставать с колен будет ещё веселей” (моє виділення - Г.К.), (КРЫМский бандеровец).

"Зато не стреляют" - мантра-самозаспокоєння, що в Україні справи набагато гірші, ніж в окупованому Криму. Безпрограшна фраза, яка може пояснити абсолютно все. Маючи впевненість у завтрашньому дні (тут простежується гра слів: як “день”, так і “дно”), адепти “Кримнаша” свято вірять у “сильну руку” - царя, який прийде і всіх урятує. На цьому грунтується

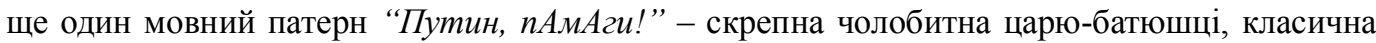
міфологема звернення до лідера нації. За спостереженнями КРИМського бандерівця, життя на військовій базі, на яку поступово перетворюється Крим, стає все веселіше, тому “вате решили напомнить про “зато не стреляют”, а то расслабились”. “Зато не стреляют. Ну как, стреляют, но не часто. Ну как, не часто - каждый день, но не насмерть. Ну как, не насмерть не всех". "Не знаю, что и почему происходит в Крыму, но это сильно напугало оккупантов. Может, они сами во “всенародную поддержку” не очень верят? Чувствую, истории “Зато не стреляют" плавно приходит конец" (моє виділення - Г.К.), (КРЫМский бандеровец).

"Вот построят мост", Крымский мост - ще одна непохитна мантра, очікування покращення життя після закінчення будівництва мосту: "Ось побудують міст і заживемо”. "Вот построят мост" [...] Да вы даже на 5 \% не представляете, какой ад, трындец, Содом и Гоморра в Крым по этому мосту припетляют!”, “Приснилось, что все крымчане, проголосовавшие за путина, построились на Крымском мосту и пошли по нему строем в россию. В ногу, чеканя шаг”. "А что, если по открытому железнодорожному мосту через Керченский пролив первым поездом прибудет “поезд дружбы” с бандеровцами?)))” (моє виділення - Г.К.), (КРЫМский бандеровец).

Правосеки и бандеровиы - збірний образ українських націоналістів і радикалів. Природжені садисти й душогуби. Масово знищують російських снігурів, розпинають маленьких хлопчиків, знущаються з попів Московського патріархату, гвалтують вагітних пенсіонерок на блокпостах. 
Татаробандеровиь - найпідліший різновид українських радикалів. Шахраї і провокатори на американській зарплатні. Денно і нощно шкодять адептам "Кримнаша", всіляко заважаючи їм "умереть в России".

Федеральная целевая программа - збірник міфів і легенд, звернених у майбутнє. Програма вже встигла припинити своє існування через брак коштів у федеральному бюджеті.

Денег нет, но вы держитесь - універсальна відповідь на безліч запитань. Офіційні настанови, план дії від окупантів та побажання кримчанам в анексованому й окупованому Криму; неофіційна програма партії “ЄСдная Росія”, озвучена чесним і відкритим політиком Дмітрієм Мєдвєдєвим. Громадська реакція на фразу демонструє спосіб мислення населення, яке звикло до економічних негараздів - гумор і стоїцизм. "Маленькое наблюдение: футболок с Димоном и надписями “держитесь” стало очень много. Самоирония и осознание того, в какой ж@пе живем” (моє виділення - Г.К.), (КРЫМский бандеровец). "Как же приятно слышать скулёж ватных пенсов в Крыму, что “пенсия у меня всего 8 тыщ. Как на неё прожить? Даже на еду не хватает". Отвечаю всегда словами "вяликого классика": денег нет, но вы держитесь" (моє виділення - Г.К.), (КРЫМский бандеровец).

У зв'язку з енергоблокадою Криму виникло ще одне слово “мегаватникі”. Воно $є$ похідним від “ватників" і базується на грі слів. Окупаційна адміністрація півострова знайшла вихід із енергоблокади у використанні генераторів-мегаваттників. Друга "т" у цьому слові відразу відпала, що й зумовило продукування численних жартів, глузувань та кепкувань на адресу окупантів. У соціальних мережах висміяли самопроголошеного голову анексованого Криму Сергія Аксьонова, який заявив, що знеструмлену Керч зігріють мегаватникі. Слова Аксьонова опублікувало РІА Новини: “Це питання номер один. Частина генераторів, які прийдуть через поромну переправу, будуть розміщені в Керчі, це насамперед. Це будуть як генератори малої потужності, так і мегаватникі”, - сказав Аксьонов. У соціальних мережах поглузували із заяви Аксьонова про “мегаватників". Блогер Деннис Саква на своїй сторінці в Facebook від 25 листопада 2015 р. написав: “Один мегаватник управляет 1000 киловатников! А киловатник, в свою очередь, - 1000 ватников! Учитывая, что население Крыма - около 2 миллионов, им хватит 2 мегаватника. Я правильно посчитал?” (Саква, 25 листопада 2015 р.). Гострослови навіть запровадили “табель про ранги у рашистів: “Ватник, Киловатник, Мегаватник” (Анекдоты на Цензор.нет, 21.06.2014).

Так звана прихильниця анексії Криму Наталія Поклонська назвала мегаватником президента РФ Володимира Путіна. Про це вона написала в Twitter від 02.12.2015: "МегаВатный Путин!” Користувачі соцмережі відразу ж висміяли цей пост. Найімовірніше, Поклонська хотіла повідомити про радісну подію для окупованого Криму - запуск першої лінії енергомосту. Але замість мегаваттника (100-ватт) Путін виявився мегаватником. "С одной буквой Т значит речь идет не о ваттах, а о вате”. “Так и пиши - с одной “Т”, умничка няш-мяш! все правильно!”. "И вся Россия - сплошные Мега-Ватники”. “Зачем нужны мегаватники? Неужели им своих ватников не хватает?” (“Прокурор” Крыма назвала Путина мегаватником, 03 декабря 2015). Варто зазначити, сама Поклонська $є$ приводом для числених жартів і висміювань через iii "анімізований” образ “нящи-мящ”, який згодом став популярним мемом після поширення в мережі жартівливого музичного відео з нею в головній ролі (Карп’як, 8 серпня 2014).

Виявом гумористичного опору російській пропаганді в Криму вважаємо обігрування мему Нехай щастить! - Нех@й шастать! Уперше встановили білборд саме з такими словами в місті Щастя, що на Луганщині, на основі співзвучності назви міста та побажання (У Щасті "поховали" Путіна - фото, 12 Березня 2017). Ю. Луценко, свого часу будучи радником Президента України та маючи беззаперечне почуття гумору, проанонсував, що незабаром на усіх пунктах пропуску з Російською Федерацією будуть встановлені білборди з написом: "Нехай щастить, или по-русски - нех...й шастать" (Цитати на Цензор.нет, 18.08.2014). Але поки що чотири білборди-попередження були облаштовані на кордоні з анексованим Кримом та біля 
центрів, де видають закордонні паспорти, зі зверненням до кримчан українською, а до зрадниківколабораціоністів - російською: “Браття, кримчани-українці! Хоч ви і під російською окупацією, проте ми вам тут завжди раді. Свропа відкриває перед вами двері. Отримуйте біометричні паспорти і мандруйте вільно цивілізованим світом. Нехай щастить!” та “Предатели и коллаборанты! Зачем вы приехали? За паспортом украинским? В Европу захотели? А что, туры по Золотому кольцу уже не интересуют? Сидите дома и ждите камней с неба! Нех@й шастать!” (“Нехай щастить!” і “Нех@й шастать!”- - на честь безвізу жителів Криму на Херсонщині зустрічають двомовні білборди (фото), 31.05.2017).

Щоденні спостереження Кримського бандерівця визначають основну думку цього дослідження: негативні умови дійсності слід сприймати тільки через позитивний емоційний стан, піднесеність духу - інакше за цих умов вижити важко. “Умереть не встать” - когдато я смеялся над этой фразой Лии Ахеджаковой, а сегодня [...] почему-то вспомнил эти слова, но совершенно в другом контексте - в контексте того, во что превращается Крым... И стало грустно...”. "Можно высмеивать происходящее в Крыму, проявлять чудеса сарказма, но как же больно видеть, как твоя малая родина потухает и превращается в уродца”, а тому, “не каждый проктолог способен рассмотреть то место, куда мы движемся” (моє виділення Г.К.), (КРЫМский бандеровец). “Шутки про Крым перестают быть смешными. Не всегда понятно шутите вы или просто рассказываете произошедшее”. "Выражение "При Украине такого не было” перестаёт быть шуткой” (моє виділення - Г.К.) (КРЫМский бандеровец). На жаль, частина жителів окупованого півострова продовжує щиро радіти “кримнашу”, жити у фальшивій реальності й увірувати в свого національного лідера Путіна. "Только сейчас осознал, что никто вчера не шутил. Просто в Крыму никому не до шуток. Может, только самые упоротые, но у них своя реальность”. “Сплошной цирк, в котором больше никто не смеётся...да это же СТРАНА 404 МГАГАГАГА” (моє виділення - Г.К.) (КРЫМский бандеровец). Але всупереч усім викликам долі “Чорне море ще всміхнеться” С після звільнення півострова від окупації. "Хотелось бы дожить до того момента, когда Крым и Донбасс будут освобождены, и мы точно так же со слезами на глазах будем вместе радоваться и поздравлять друг друга с освобождением из российского плена". “Нищим хлеба и зрелищ! 15 февраля оккупанты созывают вату Заозёрного (Евпатория) на “торжественный митинг”, посвящённый выводу советских войск из Афганистана. День ВЫВОДА российских войск мы тоже будем праздновать... Не митингом... Карнавалом!” (моє виділення - Г.К.) (КРЫМский бандеровец).

Висновки й перспективи подальших досліджень. Проаналізовані мовні патерни можемо вважати одним 3 найбільш продуктивних методів ефективного переконання. Створені в окупованому Криму лексичні новотвори, інтернет-меми, мовні патерни свідчать сміхове світосприйняття дійсності у мовній картині світу українців та україноцентричних мешканців Криму. Мовна протестна риторика з вкрапленнями гумору слугує своєрідним захисним щитом і зброєю інтелектуального ураження. Лексичні новотвори функціонують у рамках гумористичного інтрадискурсу та виконують одну з найважливіших функцій у сучасній сміховій культурі українців - висміювання опонента через жартівливу невідповідність загальноприйнятим нормам. Перспективу подальших досліджень вбачаємо в систематизації й узагальненні лексикостилістичних засобів вираження мови сміху КРИМського бандерівця. В авторському післяслові до історичного роману “Роксолана” Павло Загребельний зазначає, що “наша гідність і наш порятунок - у думці, в розумі”. Варто додати, що і гумористичне сприйняття дійсності може слугувати порятунком і звільненням від окупації, наразі хоча б у моральному плані, адже тільки вільна людина може через сміх висловити свою незгоду із сьогоденням. “Комедія людського буття" вимагає від людини бути "homo ridens” (“людиною, що сміється”), адже, за класиком, “розумне обличчя - це ще не ознака розуму; найбільші дурниці на Землі чиняться із серйозним виразом обличчя. Усміхайтеся, панове, усміхайтеся!”. 


\section{ЛIТЕРАТУРА}

Гуменюк, Л. (07 марта 2017). КРЫМский бандеровеи:: Крыци-слииком тяжельй камень на шее утопленника. Взято 3: www.obozrevatel.com/society/08972-kryimskij-banderovets-kryimslishkom-tyazhelyij-kamen-na-shee-utoplennika.htm.

Донскіс, Л. (2015). Як Путін розважає народ. Украӥнський тиждень, 47 (419), 50.

Казарин, П. (02 Январь 2016). Мегаватники, зрадофиль, гречкосейство. Какие слова подарил нам 2015 год? Взято 3: http://ru.krymr.com/content/article/27460989.html.

Карп'як, О. (8 серпня 2014). Вата з укропом: мова політичних мемів. Взято 3: http://www.bbc.com/ ukrainian/entertainment/2014/08/140807_new_words_ko.

Кирилюк, О. (2015). “Вогнехреще” або неологізми як відображення військового протистояння. Наук. зап. Сер. Філологічні науки : [зб наук пр]. Кіровоград, (137), С. 52 - 57.

Коротыч, И. (2016). Зачем это всё, или Ещё немного про аннексию Крыма. [Weblog]. Взято з: https://site.ua/irina.korotych/2407-zachem-eto-vse-ili-esche-nemnogo-pro-anneksiyu-kryma/.

Крымнаш. (4 листопада 2017). Електронна енциклопедія “Вікіпедія”. Взято з: https://uk.wikipedia.org/wiki/\%D0\%9A\%D1\%80\%D1\%8B\%D0\%BC\%D0\%BD $\%$ D0\%B0\%D $1 \% 88$.

КРЫМский бандеровец. (з 13 листопада 2014, щоденно). Новости Крымнаша. Информационное сопротивление российской оккупации Крыма и Донбасса. [Weblog]. Взято з: https://crimeaua1.wordpress.com/.

Манакін, В. М. (2012). Мова і міжкультурна комунікація. Київ: ВЦ “Академія”.

Масенко, Л. (23 Август 2017). Украина и миф Кремля о “вежливом солдате”. Взято з: https://ru.krymr.com/a/28692703.html.

Новости Крымнаша. (30 травня 2017). Електронна енциклопедія “Вікіпедія". Взято з: https://uk.wikipedia.org/wiki/\%D0\%9D\%D0\%BE\%D0\%B2\%D0\%BE\%D1\%81\%D1\%82\%D 0\%B8_\%D0\%9A\%D1\%80\%D1\%8B\%D0\%BC\%D0\%BD\%D0\%B0\%D1\%88\%D0\%B0.

Сабитова, 3. К. (2013). Лингвокультурология. Москва: Наука.

Самохіна, В. О. (2012). Жарт у сучасному комунікативному просторі Великої Британії mа США: монографія. Харків: ХНУ імені В. Н. Каразіна.

Стельмах, С. (07 Октябрь 2016). Крымское безвременье. Взято 3: http://ru.krymr.com/a/ 28038308.html.

Туркова, К. (19 березня, 2016). “Кримнаш”, “вєжлівиє люді”, “ватнік”: неологізми, породжені конфліктом. Взято 3: https://hromadske.ua/posts/krymnash-viezhlivyie-liudi-vatnik-neolo hizmy-porodzheni-konfliktom.

\section{ДЖЕРЕЛА ІЛЮСТРАТИВНОГО МАТЕРІАЛУ}

Анекдоты на Цензор.нет. (21.06.2014). Цензор.нет. Взято з: https://censor.net.ua/jokes/1041777. В Щасті “поховали” Путіна - фото. (12 Березня 2017). Politeka. Взято 3: https://politeka.net/ ua/news/413946-v-schaste-pohoronili-putina-foto/.

“Нехай щастить!” і “Нех@й шастать!” - на честь безвізу жителів Криму на Херсонщині зустрічають двомовні білборди (фото). (31.05.2017). ХЕРСОН.city. Взято 3: http://kherson.ua.city/ society/6324-nekhaj-shchastit-i-nekh-j-shastat-na-chest-bezvizu-zhiteliv-krimu-na-khersonsh chini-zustrichayut-dvomovni-bilbordi-foto.

“Прокурор” Крыма назвала Путина мегаватником (03 декабря 2015). Взято з: https://bykvu.com/ bukvy/15520-prokuror-kryma-nazvala-putina-megavatnikom.

Саква, Д. (25 листопада 2015 р.). Сторінка у соціальній мережі Facebook. Взято з: https://www.facebook.com/ dennis.sakva/posts/551504201674423. 
У админграницы с Крымом появились билборды с обращением к предателям Украины: опубликованы фото. (31 мая 2017). Апостроф. Взято 3: https://apostrophe.ua/news/society/ 2017-05-31/u-admingranicy-s-krymom-poyavilis-bilbordy-s-obrascheniem-k-predatelyamukrainy-opublikovany-foto/97469.

Цитати на Цензор.нет. (18.08.2014). Цензор.нет. Взято 3: https://censor.net.ua/quotes/54274

Чотиривірш Олександра Коноваленка. (2017). Перещь. Весела республіка, листопад (№ 11), 10.

Яковенко, И. (27/07/2017). Санкиии: очень смешно и совсем не больно. Взято з: http://www.ungazeta.info/ ?p=1062.

\section{REFERENCES}

Gumenyuk, L. (07 marta 2017). KRYMskiy banderovets: Krym-slishkom tyazhelyy kamen na sheye utoplennika. Vzyato z: www.obozrevatel.com/society/08972-kryimskij-banderovets-kryimslishkom-tyazhelyij-kamen-na-shee-utoplennika.htm.

Donskis, L. (2015). Yak Putin rozvazhaie narod. Ukrainskyi tyzhden, №47 (419), 50.

Kazarin. P. (02 Yanvar 2016). Megavatniki, zradofily, grechkoseystvo. Kakiye slova podaril nam 2015 god? Vzyato z: http://ru.krymr.com/content/article/27460989.html.

Karpiak, O. (8 serpnia 2014). Vata z ukropom: mova politychnykh memiv. Vziato z: http://www.bbc.com/ ukrainian/entertainment/2014/08/140807_new_words_ko.

Kyryliuk, O. (2015). “Vohnekhreshche” abo néolohizmy yak vidobrazhennia viiskovoho protystoiannia. Nauk. zap. Ser. Filolohichni nauky : [zb nauk pr] Kirovohrad. derzh. ped. un-t im. V. Vynnychenka. Kirovohrad, (137), S. $52-57$.

Korotych, I. (2016). Zachem eto vse, ili Eshche nemnogo pro anneksiyu Kryma. [Weblog]. Vzyato z: https://site.ua/irina.korotych/2407-zachem-eto-vse-ili-esche-nemnogo-pro-anneksiyu-kryma/.

Krymnash. (4 lystopada 2017). Elektronna entsyklopediia "Wikipedia". Vziato z: https:/luk.wikipedia.org/ wiki/\%D0\%9A\%D1\%80\%D1\%8B\%D0\%BC\%D0\%BD\%D0\%B0\%D1\%88.

KRYMskiy banderovets. (z 13 listopada 2014, shchodenno). Novosti Krymnasha. Informatsionnoye soprotivleniye rossiyskoy okkupatsii Kryma i Donbassa. [Weblog]. Vzyato z: https://crimeaua1.wordpress.com/.

Manakin, V. M. (2012). Mova i mizhkulturna komunikatsiia. Kyiv : VTs "Akademiia".

Masenko, L. (23 Avgust 2017). Ukraina i mif Kremlya o "vezhlivom soldate". Vzyato z: https://ru.krymr.com/a/28692703.html.

Novosti Krymnasha. (30 travnya 2017). Elektronna entsiklopediya "Wikipedia". Vzyato z: https://uk.wikipedia.org/wiki/\%D0\%9D\%D0\%BE\%D0\%B2\%D0\%BE\%D1\%81\%D1\%82\%D 0\%B8_\%D0\%9A\%D1\%80\%D1\%8B\%D0\%BC\%D0\%BD\%D0\%B0\%D1\%88\%D0\%B0.

Sabitova, Z. K. (2013). Lingvokulturologiya. Moskva : Nauka.

Samokhina, V. O. (2012). Zhart u suchasnomu komunikatyvnomu prostori Great Britain ta USA: monohrafiia. Kharkiv : KhNU imeni V. N. Karazina.

Stelmakh, S. (07 Oktyabr 2016). Krymskoye bezvremenye. Vzyato z: http://ru.krymr.com/a/ 28038308.html.

Turkova, K. (19 bereznia, 2016). "Krymnash”, “viezhlivyie liudi”, “vatnik”: neolohizmy, porodzheni konfliktom. Vziato z: https:/hromadske.ua/posts/krymnash-viezhlivyie-liudi-vatnik-neolo hizmy-porodzheni-konfliktom.

Anekdoty na Tsenzor.net. (21.06.2014). Tsenzor.net. Vzyato z: https://censor.net.ua/jokes/1041777.

V Shchasti “pokhovaly” Putina - foto. (12 Bereznia 2017). Roliteka. Vziato z: https://politeka.net/ ua/news/413946-v-schaste-pohoronili-putina-foto/.

"Nekhai shchastyt!” i “Nekh@i shastat!” - na chest bezvizu zhyteliv Krymu na Khersonshchyni zustrichaiut dvomovni bilbordy (foto). (31.05.2017). KhERSON.city. Vziato z: http://kherson.ua.city/ society/6324-nekhaj-shchastit-i-nekh-j-shastat-na-chest-bezvizu-zhiteliv-krimu-na-khersonshchinizustrichayut-dvomovni-bilbordi-foto. 
"Prokuror" Kryma nazvala Putina megavatnikom (03 dekabrya 2015). Vzyato z: https://bykvu.com/ bukvy/15520-prokuror-kryma-nazvala-putina-megavatnikom.

Sakva, D. (25 lystopada 2015 r.). Storinka u sotsialnii merezhi Facebook. Vziato z: https://www.facebook.com/dennis.sakva/posts/551504201674423.

$\mathrm{U}$ admingranitsy s Krymom poyavilis bilbordy s obrashcheniyem k predatelyam Ukrainy: opublikovany foto. (31 maya 2017). Apostrof. Vzyato z: https://apostrophe.ua/news/society/2017-05-31/ u-admingranicy-s-krymom-poyavilis-bilbordy-s-obrascheniem-k-predatelyam-ukrainyopublikovany-foto/97469.

Tsitaty na Tsenzor.net. (18.08.2014). Tsenzor.net. Vzyato z: https://censor.net.ua/quotes/54274.

Chotyryvirsh Oleksandra Konovalenka. (2017). Perets. Vesela respublika, lystopad (№ 11), 10.

Yakovenko, I. (27/07/2017). Sanktsii: ochen smeshno $i$ sovsem ne bolno. Vzyato z: http://www.ungazeta.info/?p=1062. 